\title{
経尿道的前立腺切除術の臨床的検討
}

\begin{tabular}{|c|c|c|c|c|}
\hline & 工 & & & 潔 \\
\hline & 木 & 村 & 光 & 隆 \\
\hline & 松 & 原 & 正 & 典 \\
\hline & 諏 & 訪 & 純 & . \\
\hline 杏林大学泌层器科学教室 & 三 & 村 & 晴 & \\
\hline (主任：千野一郎教授） & 松 & 山 & 恭 & 輔 \\
\hline & 青 & 柳 & 直 & 大 \\
\hline & 宾 & & & \\
\hline & 千 & 野 & 武 & \\
\hline & 千 & 野 & 一 & 郎 \\
\hline
\end{tabular}

\section{CLINICAL EVALUATION OF TRANSURETHRAL PROSTATIC RESECTION}

\author{
Kiyoshi Kudoh, Mitsutaka Kimura, Masanori Matsubara, Junji Suwa, Haruo Mimura, \\ Kyosuke Matsuyama, Naohiro Aoyagi, Satoru Shishido, Takehiro Chino \\ and Ichiro Chino \\ Department of Urology, Kyorin University School of Medicine \\ (Director: Prof. I. Chino)
}

Transurethral prostatic resection (TUR) is now established as an alternative to open surgery. The indicative criteria of TUR, however, has not yet clearly defined, because the selection of the operative methods for BPH is influenced by surgeon's preference.

During the 8-year period between January, 1976 and December, 1983, 159 patients operated upon for $\mathrm{BPH}$ were reviewed by comparing the results of 125 TUR on 121 cases (T. group) and 38 open surgery ( $\mathrm{O}$. group) as to hematuria period, catheter drainage period, admission period and complication after operation.

Furthermore $\mathrm{T}$ group was evaluated regarding catheter drainage, pyuria, azotemia and anemia before operation, patient age, operation time and weight of resected specimen using the same criteria as above.

The results were as follows:

1) $T$. group as superior to $O$. group in several respects, that is 2.1 days of hematuria period vs. 5.7 days, 4.3 days of catheter drainage period vs. 10.7 days, 15.4 days on admission period vs. 25.5 days and $28 \%$ of complication after operation vs. $31.6 \%$.

2) There existed a positive correlation between operation time and weight of resected specimen in $\mathrm{T}$. group, but not in $\mathrm{O}$. group. In the former group $0.23 \mathrm{~g}$ were resected per minute, while in the latter $0.31 \mathrm{~g}$ However, when limited cases with resected specimen below $40 \mathrm{~g}$ were compared, $\mathrm{T}$. group was superior to $O$. group by 0.23 vs. $0.20 \mathrm{~g} / \mathrm{min}$.

3) Evaluation of $T$. group suggested that preoperative catheter drainage, preoperative pyuria and older age above 80 tended to affect adversely.

4) In TUR, operation time and weight of resected specimen paralleled the age of patient, and as operation time prolonged and weight of resected specimen increased, operative result was prone to be affected adversely.

In conclusion, it is suggested that early operation for symptomatic BPH with the gland clinically 
estimated less than $50 \mathrm{~g}$, control of preoperative pyuria, and limit of resection time within 120 minutes were important factors for stable TUR.

要旨：前立腺肥大症の手術法としての経尿道的切除術（TURP）の地位は定着したが，手術法の選択は 術者の好みに左右され，その適応基準は明示されていないそそこで，われわれが，1976年 1 月より 1983 年12月までの 8 年間に手術を行った159例の前立腺肥大症を TURP (T群)121例, 125回と open sargery (O 群)38例に分け, 術後の血尿期間，カテーテル留置期間，入院期間，合併症などを成績の指標として， 比較検討した. 次いで, TURP 症例について, 術前の留置カテーテル, 膿尿, 高窒素血症, 䝯血, 年齢, 手術時間，切除組織重量などを上記成績の指標と関連させ，検討した。

その結果は以下の如くであった。

1） $\mathrm{T}$ 群と $\mathrm{O}$ 群の術後の血尿期間，カテーテル留置期間，入院期間，そして合併症の頻度は各，2.1日 対5.7日，4.3日対10.7日，15.4日対 25.5 日そして $28 \%$ 対 $31.6 \%$ ありり，何れも T群が優っていた。

2） T群では手術時間と切除量の間に正の相関関係がみられたが，O群では関連性みられず，切除率は 各, $0.23 \mathrm{~g} / \mathrm{min}, 0.31 \mathrm{~g} / \mathrm{min}$ であった。しかし，切除量 $40 \mathrm{~g}$ 以下では各， $0.23 \mathrm{~g} / \mathrm{min}, 0.20 \mathrm{~g} / \mathrm{min}$ となり, T群が $\mathrm{O}$ 群に優る傾向を示した。

3）TUR 症例の検討から，術前の留置カテーテル，膿尿の存在，80歳以上の高龄患者では，成績不良 となる傾向がみられた。

4）TURの手術時間，切除量は患者の年齢と平行関係にあり，手術時間の延長，切除量の増加にした がって，手術成績の不良となる傾向が示された。

結論として, 安定した TUR を行らために, 排尿障害発症後は早期に手術を考慮し, 腺腫 $50 \mathrm{~g}$ 以下の症 例を適応とし， 2 時間の手術時間を順守することが肝要と思われた。

\section{緒言}

近年，わが国の平均寿命の延長に伴い，高齢疾患で あり，加齢に伴う生理的現象の結果とも言われる前立 腺肥大症が増加している，良性疾患である本症の治療 は可及的非侵襲的であるべきであり,その趣旨に沿い, 種々の非観血的治療が行われている。しかし，何れも 姑息的な感は否めず，特に第II期以上では，結局，手 術的治療に頼らざるを得ないのが現状と言える。

手術法は，従来の開創手術に代り，今や，経尿道的 切除術（TUR）が第一選択法として確立された感があ る。しかし，手術法の選択は術者の好みに依存してお ク，いまだ適応基準は示されていない，勿論，この点 は術者の技術に大きく左右されるわけであるが，平均 的適応基準の設定は可能と思われる。

そこで, 当教室での TUR 症例を検討し，その可能性 を考察し，報告する。

\section{対象および方法}

対象症例は1976年 1 月から1983年12月までの 8 年間 に杏林大学病院泌尿器科で前立腺肥大症々診断され,

入院手術を受けた159例である。

先ず，症例を TUR（T群）と開創手術（O群）の 2 群に分け, 比較検討し, 次いでT群について, 治療成
績に影響をおよぼすと考えられる諸因子に関して検討 した。な拉，TURは121例に対し，再手術 4 例を含め 125回行った。 また，以下の検討事項のうち，対象とし て不適当と考兄られた症例は除外したので，項目によ り症例数が異なる。

\section{検討事項および結果}

1. 経尿道的手術と開創手術の比較

1）前立腺肥大症症例（Table 1)

入院手術を受けた患者は159例であり，経時的に, や や増加傾向がみられた. TUR は年平均 $73.0 \%$, 全体で $76.1 \%$ に行われたのに対し，開創手術は各，27\%，

Table 1 Annual case and operative method

\begin{tabular}{c|c|r|c}
\hline Year & BPH & TUR (\%) & OPEN (\%) \\
\hline 1976 & 12 & $3(25.0)$ & $9(75.0)$ \\
1977 & 15 & $10(66.7)$ & $5(33.3)$ \\
1978 & 17 & $16(94.1)$ & $1(5.9)$ \\
1979 & 23 & $17(73.9)$ & $6(26.1)$ \\
1980 & 16 & $12(75.0)$ & $4(25.0)$ \\
1981 & 21 & $17(81.0)$ & $4(19.0)$ \\
1982 & 24 & $18(75.0)$ & $6(25.0)$ \\
1983 & 31 & $28(90.3)$ & $3(9.7)$ \\
\hline Total & 159 & $121(76.1)$ & $38(23.9)$ \\
\hline
\end{tabular}


23.9\%であった。

2) 年齢 (Table 2)

年齢分布は $\mathrm{T}$ 群では51歳から 85 歳, 平均 71.5 歳, $\mathrm{O}$ 群では51歳から92歳, 平均69.6歳であり, 年齢差は認 められなかったが，80歳以上の症例はT群に多くみら れた。

3）手術法挹よび麻酔法（Table 3,4）

術式の比率は TUR 76.1\%, 恥骨後式摘除術 (RPP) $21.4 \%$, 恥骨上式摘除術 (SPP) $2.5 \%$ であり, 麻酔法 は T群で腰麻，O群で全麻が多い傾向であった。

4) 術後経過（Table 5,6）

$\mathrm{T}$ 群と $\mathrm{O}$ 群の輸血頻度, 術後血尿期間, カテーテル 留置期間，入院期間を比較すると，各， $34 \%$ 対 $71 \%$, 2.1 日対 5.7 日，4.3日対 10.7 日，15.4日対 25.5 日であっ た。 ま, 術中, 術後の合併症はT群で125例中28例, $22.4 \%$ に 35 件， $28 \%$ ，O群で 38 例中 8 例， $21.1 \%$ に 12 件, $31.6 \%$ みられ，その主なものは，T群では出血， 副辠丸炎, 尿失禁, 穿孔, 再手術など, O群では肝炎, 瘻孔, 副粹丸炎などであった。また, 死亡は両群に 1

Table 2 Age distribution

\begin{tabular}{l|r|r|r}
\hline Age & TUR (\%) & OPEN (\%) & Total (\%) \\
\hline$\sim 59$ & $3(2.4)$ & $2(5.3)$ & $5(3.1)$ \\
$60 \sim 69$ & $45(37.2)$ & $14(36.8)$ & $59(37.1)$ \\
$70 \sim 79$ & $59(48.8)$ & $20(52.6)$ & $79(49.7)$ \\
$80 \sim 89$ & $14(11.6)$ & $1(2.7)$ & $15(9.4)$ \\
$90 \sim$ & $0(0.0)$ & $1(2.7)$ & $1(0.6)$ \\
\hline $\begin{array}{l}\text { Mean of } \\
\text { Age }\end{array}$ & 71.5 & 69.6 & \\
\hline
\end{tabular}

Table 3 Operative method

\begin{tabular}{c|c}
\hline Method & No. of patients (\%) \\
\hline TUR & $121(76.1)$ \\
RPP & $34(21.4)$ \\
SPP & $4(2.5)$ \\
\hline Total & $159(100.0)$ \\
\hline
\end{tabular}

Table 4 Anesthetic method

\begin{tabular}{l|r|r}
\hline \multicolumn{1}{c|}{ Method } & \multicolumn{1}{|c|}{ TUR (\%) } & OPEN (\%) \\
\hline General & $35(28.0)$ & $28(73.7)$ \\
General+Epidural & $1(0.8)$ & $1(2.6)$ \\
Spinal & $72(57.6)$ & $1(2.6)$ \\
Epidural & $17(13.6)$ & $8(21.1)$ \\
\hline \multicolumn{1}{c}{ Total } & $125(100.0)$ & $38(100.0)$ \\
\hline
\end{tabular}

Table 5 Postoperative course

\begin{tabular}{l|c|c|c|c}
\hline \multirow{2}{*}{} & \multicolumn{2}{|c|}{ TUR } & \multicolumn{2}{c}{ OPEN } \\
\cline { 2 - 5 } & $\mathrm{N}$ & $\mathrm{M} \pm \mathrm{SD}$ & $\mathrm{N}$ & $\mathrm{M}+\mathrm{SD}$ \\
\hline $\begin{array}{c}\text { Blood transfusion } \\
\text { (incidence) }\end{array}$ & 125 & $0.34 \pm 0.47$ & 38 & $0.71 \pm 0.46$ \\
$\begin{array}{c}\text { Hematuria } \\
\text { (day) }\end{array}$ & 123 & $2.1 \pm 3.5^{*}$ & 38 & $5.7 \pm 5.1^{*}$ \\
$\begin{array}{c}\text { Catheter } \\
\text { (day) }\end{array}$ & 113 & $4.3 \pm 2.2^{*}$ & 35 & $10.7 \pm 4.6^{*}$ \\
$\begin{array}{c}\text { Hospitalization } \\
\text { (day) }\end{array}$ & 112 & $15.4 \pm 6.0^{*}$ & 33 & $25.5 \pm 11.3^{*}$ \\
$\begin{array}{c}\text { Complication } \\
\text { (incidence) }\end{array}$ & 125 & $0.28 \pm 0.45$ & 38 & $0.32 \pm 0.46$ \\
\hline
\end{tabular}

(*: $\mathrm{P}<0.01)$

Table 6 Postoperative complication

\begin{tabular}{l|rr|rl}
\hline & No & $\%$ & No & $\%$ \\
\hline Bleeding & 9 & 7.2 & 2 & 5.3 \\
Epididymitis & 5 & 4.0 & 2 & 5.3 \\
Incontinence & 5 & 4.0 & 1 & 2.6 \\
Perforation & 4 & 3.2 & & \\
Re-operation & 4 & 3.2 & & \\
Mental confusion & 3 & 2.4 & 1 & 2.6 \\
Hepatitis & & & 3 & 7.9 \\
Fistula & & & 2 & 5.3 \\
Gastric ulcer & & & 1 & 2.6 \\
Others & 5 & 4.0 & & \\
\hline \multicolumn{1}{c}{ Total } & 35 & 28.0 & 12 & 31.6 \\
\hline
\end{tabular}

例宛みられ，T例は DIC による出血死であり，O例は 出血, 瘦孔, ストレス性胃潰瘍に起因するものと考兄 られた。

\section{5）手術による臨床検査成績の変動（Table 7）}

術前, 術翌日， 7 日目の血液 $\mathrm{Hb}, \mathrm{Ht}$, 血清クレアチ ニン, 電解質を検討した. $\mathrm{Hb}, \mathrm{Ht}$. 值はT群, $\mathrm{O}$ 群とも に術後 $1.0 \sim 2.0 \mathrm{~g} / \mathrm{dl}, 3.0 \sim 6.0 \%$ 減少し, その低値は 1 週間持続したが，両群間で有意差はみられなかった。 血清 $\mathrm{Cr}$. 值は両群とも, 術後軽度の上昇を示したが, 7 日目には術前値に復した。 また，血清 $\mathrm{Na}, \mathrm{Cl}, \mathrm{K}$ 值は， 何れも術後低下傾向を示したが，7日目には注沭前 値に復し，両群間に有意差は認められなかった。

6) 手術時間と切除組織重量 (Table 8,Fig. 1)

出血と穿孔のため開腹手術を行った 1 例を除いた 124回の TURの手術時間は22分から270分，平均 $69.8 \pm 30.6$ 分, 切除量は $3 \mathrm{~g}$ から $52 \mathrm{~g}$, 平均 $16.2 \pm 9.9 \mathrm{~g}$ であり, 切除率 $0.23 \pm 0.11 \mathrm{~g} / \mathrm{min}$ であった。一方, O 群では各, $141.3 \pm 40.3$ 分, $44.3 \pm 32 \mathrm{~g}, 0.31 \pm 0.23 \mathrm{~g} /$ minであった。 
Table 7 Serial laboratory studies following operation

\begin{tabular}{l|c|r|r|r|r|r|r}
\hline \multicolumn{2}{c}{} & \multicolumn{2}{c|}{ Pre-ope. } & \multicolumn{2}{c|}{ Post-ope, 1d. } & \multicolumn{2}{c}{ Post-ope 7d. } \\
\cline { 3 - 8 } \multicolumn{2}{c|}{} & \multicolumn{1}{c|}{$\mathrm{N}$} & $\mathrm{M} \pm \mathrm{SD}$ & $\mathrm{N}$ & $\mathrm{M} \pm \mathrm{SD}$ & $\mathrm{N}$ & $\mathrm{M} \pm \mathrm{SD}$ \\
\hline \multirow{2}{*}{$\mathrm{Hb}(\mathrm{g} / \mathrm{dl})$} & $\mathrm{T}$ & 127 & $14.0 \pm 1.7$ & 123 & $12.3 \pm 1.6$ & 116 & $12.4 \pm 1.7$ \\
& $\mathrm{O}$ & 37 & $13.9 \pm 1.6$ & 36 & $12.9 \pm 1.5$ & 28 & $12.5 \pm 1.4$ \\
\hline \multirow{2}{*}{$\mathrm{Ht}(\%)$} & $\mathrm{T}$ & 125 & $41.1 \pm 4.3$ & 125 & $35.5 \pm 5.2$ & 115 & $36.5 \pm 4.8$ \\
& $\mathrm{O}$ & 36 & $40.5 \pm 4.0$ & 35 & $37.6 \pm 4.4$ & 28 & $37.4 \pm 4.1$ \\
\hline \multirow{2}{*}{$\mathrm{Cr}(\mathrm{mg} / \mathrm{dl})$} & $\mathrm{T}$ & 125 & $1.1 \pm 0.3$ & 101 & $1.3 \pm 0.3$ & 118 & $1.1 \pm 0.3$ \\
& $\mathrm{O}$ & 35 & $1.2 \pm 0.3$ & 26 & $1.3 \pm 0.4$ & 31 & $1.0 \pm 0.2$ \\
\hline \multirow{2}{*}{$\mathrm{Na}(\mathrm{mEq} / \mathrm{L})$} & $\mathrm{T}$ & 124 & $141.3 \pm 2.6$ & 103 & $139.3 \pm 4.9$ & 116 & $140.2 \pm 2.9$ \\
& $\mathrm{O}$ & 36 & $141.1 \pm 2.5$ & 27 & $138.6 \pm 3.7$ & 31 & $139.5 \pm 3.9$ \\
\hline \multirow{2}{*}{$\mathrm{Cl}(\mathrm{mEq} / \mathrm{L})$} & $\mathrm{T}$ & 125 & $103.9 \pm 3.0$ & 104 & $101.6 \pm 4.5$ & 115 & $102.6 \pm 3.4$ \\
& $\mathrm{O}$ & 36 & $103.7 \pm 3.8$ & 28 & $101.3 \pm 4.4$ & 30 & $101.7 \pm 3.2$ \\
\hline \multirow{2}{*}{$\mathrm{K} \mathrm{(mEq/L)}$} & $\mathrm{T}$ & 125 & $4.2 \pm 0.4$ & 104 & $3.8 \pm 0.5$ & 115 & $4.2 \pm 0.5$ \\
& $\mathrm{O}$ & 35 & $4.3 \pm 0.4$ & 28 & $4.0 \pm 0.4$ & 31 & $4.4 \pm 0.5$ \\
\hline
\end{tabular}

( $\mathrm{T}$ : TUR group, $\mathrm{O}$ : open surgery group)

Table 8 Relationship between operation time and weight of the removed adenoma

\begin{tabular}{|c|c|c|c|c|c|c|c|c|c|}
\hline $\min$ & & $<6$ & $6 \sim 10$ & $11 \sim 20$ & $21 \sim 30$ & $31 \sim 40$ & $41 \sim 50$ & $50<$ & Total \\
\hline$<31$ & $\begin{array}{l}\mathrm{T} \\
\mathrm{O}\end{array}$ & 9 & 2 & & & & & & $\begin{array}{r}11 \\
0\end{array}$ \\
\hline $31 \sim 60$ & $\begin{array}{l}\mathrm{T} \\
\mathrm{O}\end{array}$ & 9 & 16 & 18 & 2 & 1 & & & $\begin{array}{r}46 \\
0\end{array}$ \\
\hline $61 \sim 90$ & $\begin{array}{l}\mathrm{T} \\
\mathrm{O}\end{array}$ & 1 & 5 & $\begin{array}{r}26 \\
1\end{array}$ & 18 & 3 & & 1 & $\begin{array}{r}53 \\
2\end{array}$ \\
\hline $91 \sim 120$ & $\begin{array}{l}\mathrm{T} \\
\mathrm{O}\end{array}$ & & $\begin{array}{l}2 \\
1\end{array}$ & $\begin{array}{l}3 \\
2\end{array}$ & $\begin{array}{l}3 \\
4\end{array}$ & $\begin{array}{l}1 \\
2\end{array}$ & 2 & 1 & $\begin{array}{r}12 \\
9\end{array}$ \\
\hline $121 \sim 150$ & $\begin{array}{l}\mathrm{T} \\
\mathrm{O}\end{array}$ & & & 1 & 2 & 3 & 2 & 6 & $\begin{array}{r}1 \\
13\end{array}$ \\
\hline $151 \sim 180$ & $\begin{array}{l}\mathrm{T} \\
\mathrm{O}\end{array}$ & & & 1 & 2 & 1 & 1 & 1 & $\begin{array}{l}0 \\
6\end{array}$ \\
\hline $180<$ & $\begin{array}{l}\mathrm{T} \\
\mathrm{O}\end{array}$ & & & & & $\begin{array}{l}1 \\
1\end{array}$ & & 2 & $\begin{array}{l}1 \\
3\end{array}$ \\
\hline Total & $\begin{array}{l}\mathrm{T} \\
\mathrm{O}\end{array}$ & $\begin{array}{r}19 \\
0\end{array}$ & $\begin{array}{r}25 \\
1\end{array}$ & $\begin{array}{r}48 \\
4\end{array}$ & $\begin{array}{r}23 \\
8\end{array}$ & $\begin{array}{l}6 \\
7\end{array}$ & $\begin{array}{l}2 \\
3\end{array}$ & $\begin{array}{r}1 \\
10\end{array}$ & $\begin{array}{r}124 \\
33\end{array}$ \\
\hline
\end{tabular}

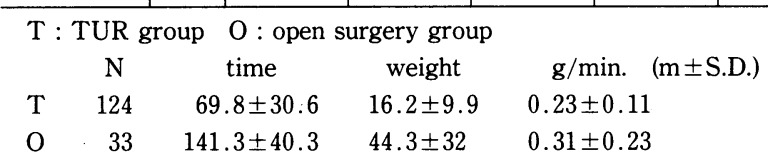

手術時間と切除量の関係をみると, $\mathrm{T}$ 群では $\mathrm{r}=$ $0.59(\mathrm{p}<0.01)$ と有意に正の相関関係がみられたが, O群では関連性は認められなかった。

\section{TUR 症例の検討}

1) TUR の頻度, 内訳 (Table 9, 10)
入院手術中に占める TUR の頻度は27.3\%であり， その内訳は前立腺肥大症 (40.7\%) と膀胱腫瘍 (30.6\%) が大半を占めた。
2) TUR の成績
経尿道的前立腺切除術（TURP）の成績に影響する 
Fig. 1 Operation time and weight of removed adenoma

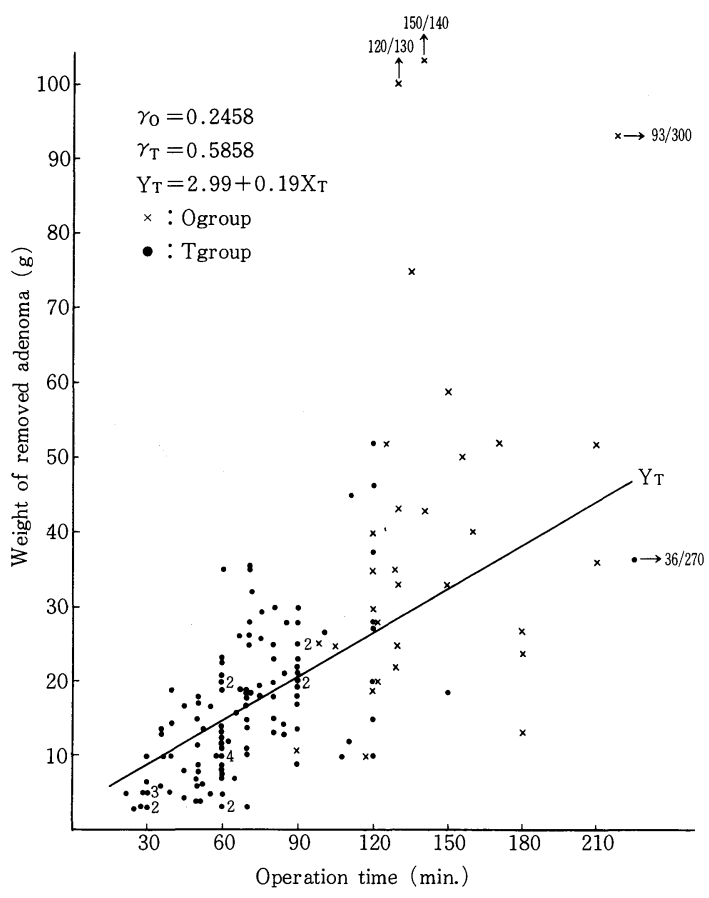

と考えられる諸因子を上げ，術後の血尿持続期間，カ テーテル留置期間，入院期間扣よび合併症を成績のパ ラメーターとして関連させ，検討した。

（1）術前留置カテーテル（Table 11）

術前カテーテル留置症例は 53 例， $42.4 \%$ にられ， 検討可能な 51 例と非留置症例の間に血尿期間，カテー テル留置期間に差をみなかったが，前者は入院期間が 長 $<(p<0.01)$, 合併症の多い $(\mathrm{p}<0.05)$ 傾向を示し た.

（2）膿尿（Table 11）
Table 9 Incidence of TUR

\begin{tabular}{c|c|c}
\hline & Operation & TUR (\%) \\
\hline 1976 & 100 & $26(26.0)$ \\
1977 & 122 & $30(24.6)$ \\
1978 & 126 & $34(27.0)$ \\
1979 & 132 & $37(28.0)$ \\
1980 & 155 & $39(25.2)$ \\
1981 & 184 & $41(22.3)$ \\
1982 & 147 & $42(28.6)$ \\
1983 & 160 & $58(36.3)$ \\
\hline Total & 1,126 & $307(27.3)$ \\
\hline
\end{tabular}

Table 10 Reason for TUR

\begin{tabular}{l|r}
\hline & No. (\%) \\
\hline BPH & $125(40.7)$ \\
Bladder tumor & $94(30.6)$ \\
Biopsy & $34(11.1)$ \\
Prostatic cancer & $15(4.9)$ \\
Chronic cystitis & $11(3.6)$ \\
Others & $28(9.1)$ \\
\hline \multicolumn{1}{c|}{ Total } & $307(100.0)$ \\
\hline
\end{tabular}

尿中白血球 $10 / \mathrm{HPF}$. 以上を示した症例は 54 例, $44.6 \%$ にられ，検討可能な 51 例を対象とした膿尿の 有無による血尿期間，カテーテル留置期間に差はみら れなかったが，膿尿群では入院期間が長く $(p<0.01)$ ， 合併症の多い（ $\mathrm{p}<0.05 ）$ 傾向を示した.

(3) 高窒素血症 (Table 11)

BUN $25.0 \mathrm{mg} / \mathrm{dl}$ 以上あるいは血清クレアチニン $1.5 \mathrm{mg} / \mathrm{dl}$ 以上の高窒素血症は 20 例， $15.9 \%$ にみられ たが，高窒素血症の有無による術後経過に差は認めら れなかった。

（4）負血 (Table 11)

Table 11 Relationship between preoperative condition and postoperative course in TUR

\begin{tabular}{l|c|c|c|c|c|c}
\hline \multicolumn{2}{l|}{} & $\mathrm{N}$ & $\begin{array}{c}\text { Hematuria } \\
\text { (day) }\end{array}$ & $\begin{array}{c}\text { Catheter } \\
\text { (day) }\end{array}$ & $\begin{array}{c}\text { Hospital } \\
\text { (day) }\end{array}$ & $\begin{array}{c}\text { Complication } \\
\text { (incidence) }\end{array}$ \\
\hline \multirow{3}{*}{ Catheter } & + & 51 & $2.0 \pm 3.9$ & $4.5 \pm 2.5$ & $15.8 \pm 6.6$ & $0.4 \pm 0.5$ \\
& - & 71 & $2.1 \pm 3.2$ & $4.2 \pm 2.3$ & $14.2 \pm 4.4^{*}$ & $0.1 \pm 0.4^{\dagger}$ \\
Pyuria & + & 51 & $1.7 \pm 3.9$ & $4.4 \pm 2.5$ & $16.4 \pm 7.2$ & $0.3 \pm 0.5$ \\
& - & 68 & $2.4 \pm 3.7$ & $4.4 \pm 2.4$ & $14.0 \pm 4.2^{*}$ & $0.2 \pm 0.4^{\dagger}$ \\
Azotemia & + & 20 & $1.6 \pm 1.4$ & $4.6 \pm 3.2$ & $16.6 \pm 6.7$ & $0.3 \pm 0.5$ \\
& - & 100 & $2.2 \pm 3.8$ & $4.4 \pm 2.3$ & $14.9 \pm 5.4$ & $0.2 \pm 0.4$ \\
Anemia & + & 17 & $1.5 \pm 2.0$ & $4.3 \pm 1.9$ & $13.9 \pm 5.7$ & $0.2 \pm 0.4$ \\
& - & 105 & $2.3 \pm 3.7$ & $4.4 \pm 2.5$ & $15.1 \pm 5.7$ & $0.2 \pm 0.4$ \\
\hline
\end{tabular}

$\left({ }^{*}: \mathrm{P}<0.01,+\dagger^{\prime} \mathrm{P}<0.05\right.$, mean \pm S.D. $)$ 
Table 12 Relationship between age, operation time, weight of resected tissue and postoperative course in TUR

\begin{tabular}{|c|c|c|c|c|c|c|c|c|}
\hline & & $\mathrm{N}$ & $\begin{array}{l}\text { Time } \\
\text { (min.) }\end{array}$ & $\begin{array}{l}\text { Tissue } \\
(\mathrm{g})\end{array}$ & $\underset{\text { (day) }}{\text { Hematuria }}$ & $\begin{array}{l}\text { Catheter } \\
\text { (day) }\end{array}$ & $\begin{array}{l}\text { Hospital } \\
\text { (day) }\end{array}$ & $\begin{array}{c}\text { Complication } \\
\text { (incidence) }\end{array}$ \\
\hline \multirow{4}{*}{$\begin{array}{l}\text { Age } \\
\text { (y.o.) }\end{array}$} & (A) $\quad \sim 69$ & 49 & $68.1 \pm 23.6$ & $19.5 \pm 9.2$ & $2.1 \pm 2.8$ & $4.0 \pm 2.2$ & $14.8 \pm 5.9$ & $0.2 \pm 0.4$ \\
\hline & (B) $70 \sim 79$ & 62 & $70.5 \pm 35.6$ & $16.2 \pm 9.6]^{\dagger}$ & $2.0 \pm 3.5$ & $4.4 \pm 2.1$ & $16.1 \pm 7.7$ & $0.2 \pm 0.4$ \\
\hline & (C) $80 \sim$ & 11 & $68.6 \pm 28.5$ & $20.0 \pm 14.3$ & $3.2 \pm 5.8$ & $4.8 \pm 1.9$ & $16.9 \pm 5.3$ & $0.4 \pm 0.5$ \\
\hline & & & $\begin{array}{c}\text { Age } \\
\text { (y.o.) }\end{array}$ & $\begin{array}{c}\text { Tissue } \\
\text { (g.) }\end{array}$ & & & & \\
\hline \multirow{4}{*}{$\underset{(\min )}{\text { Time }}$} & (A) $\quad \sim 60$ & 59 & $71.2 \pm 6.5$ & $*[10.4 \pm 6.5$ & $1.5 \pm 2.17^{*}$ & $* 3.9 \pm 2.0$ & $*[13.9 \pm 5.0$ & $0.2 \pm 0.4$ \\
\hline & (B) $61 \sim 90$ & 51 & $71.1 \pm 6.6$ & $19.9 \pm 7.1]^{*}$ & ${ }^{*}[1.9 \pm 2.9$ & $4.4 \pm 1.97^{*}$ & $\lfloor 16.3 \pm 6.9]^{\dagger}$ & $0.2 \pm 0.4$ \\
\hline & (C) $91 \sim$ & 14 & $73.4 \pm 7.2$ & {$[27.4 \pm 14.2]$} & $6.1 \pm 7.2$ & $6.2 \pm 3.3$ & $15.6 \pm 3.9]$ & $0.4 \pm 0.5$ \\
\hline & & & $\begin{array}{c}\text { Age } \\
\text { (y.o.) }\end{array}$ & $\begin{array}{l}\text { Time } \\
(\min .)\end{array}$ & & & & \\
\hline \multirow{3}{*}{$\begin{array}{l}\text { Tissue } \\
(\mathrm{g})\end{array}$} & (A) $\sim 10$ & 44 & $70.4 \pm 7.3$ & $52.1 \pm 20.4$ & $* 1.6 \pm 2.3$ & $3.9 \pm 2.0$ & $14.6 \pm 5.2$ & $0.2 \pm 0.4$ \\
\hline & (B) $11 \sim 30$ & 71 & $71.3 \pm 6.2$ & $74.5 \pm 20.6\rceil^{*}$ & $2.0 \pm 2.9\}^{*}$ & $4.6 \pm 2.3$ & $15.4 \pm 6.5$ & $0.2 \pm 0.4$ \\
\hline & (C) 31 & 9 & $74.1 \pm 7.5$ & $\lfloor 113.3 \pm 60.0\rfloor$ & $6.9 \pm 7.8$ & $5.8 \pm 3.8$ & $15.9 \pm 4.1$ & $0.6 \pm 0.5$ \\
\hline
\end{tabular}

$\left({ }^{*}: \mathrm{P}<0.01,+{ }^{\dagger}: \mathrm{P}<0.05\right.$, mean \pm S.D. $)$

$\mathrm{Hb} 11.0 \mathrm{~g} / \mathrm{dl}$ 以下あるいは $\mathrm{Ht} 35 \%$ 以下の負血症例 は17例，13.5\%にみられたが，貧血の有無による術後 経過に差は認められなかった。

次いで, 年齢, 手術時間, 切除組織量の相互関連性, さらに術後経過への影響につき検討した。

（5）年龄 (Table 12)

症例を, (A69歳以下, (B70 79歳, (C) 80 歳以上の 3 群に分けて検討した。手術時間には差がなく，切除量 は(C)群は(B)群に比し多かったが $(\mathrm{p}<0.05)$, (A)(B)間, (A) (C)間に有意差は認められなかった。血尿期間，カテー テル留置期間は(C)群で長く, 入院期間は(A)群で短く, 合併症は(C)群で多い傾向を示したが，何れにも有意差 は認められなかった。

(6) 手術時間 (Table 12)

手術時間を, (A60分以下, (B) $61 \sim 90$ 分，(C)91分以上 の 3 群に分けて検討した。年齢は(C)群に高い傾向がみ られたが有意差はなかった。切除量は(C)群に多く $(\mathrm{p}<$ $0.01)$ ，血尿期間，カテーテル留置期間も (C)群に長い (各， $\mathrm{p}<0.01$ ) 傾向がみられた。 入院期間は (B)群が(A) 群 $(\mathrm{p}<0.01)$, (C)群 $(\mathrm{p}<0.05)$ に比し長かった。また, 合併症も群に多い傾向はみられたが，有意差は認め られなかった。

(7) 切除組織重量 (Table 12)

切除量を, (A) $10 \mathrm{~g}$ 以下, (B) $11 \sim 30 \mathrm{~g}$, (C) $31 \mathrm{~g}$ 以上の 3 群 に分けて検討した。年龄は(C)群に高い傾向がみられた が有意差はなかった。手術時間, 血尿期間は(C群が, (A)，(B群に比し長かったが(各, p<0.01), (A)(群間で は有意差が認められなかった。 また，カテーテル留置
期間, 入院期間, 合併症は切除量に比例して増加する 傾向を示したが, 何れにも有意差は認められなかった。

3）合併症

(1) 術前合併症

心電図上，異常所見は63例，52.1\%にみられ，その うち 31 例, $25.6 \%$ が心筋障害など阻血性変化であった。 膿尿は54例， $44.6 \%$ によれ，そのうち42例， $34.7 \%$ はカテーテル留置例であった。 その他, 高窒素血症 (15.9\%), 貧血 $(13.5 \%)$, 糖尿病 $(5.0 \%)$, 膀胱結石 （3.3\%）などが術前合併症の主なものであった。

（2）術後合併症 (Table 6)

術後合併症は28例， $22.4 \%$ に35件認められた。術後 早期の強血尿 5 例拉よび術後 1 力月以内の後出血 4 例 の計 9 例, $7.2 \%$ に異常出血がみられ, そのらち 4 例, $3.2 \%$ 再 TUC が行われ，1例は DICにより術翌日 に死亡した。副粹丸炎は 5 例， $4.0 \%$ たたが，何れも 術前膿尿のみられた症例であり, TUR 前に精管結禁 術を行った14例中にはみられなかった。尿失禁は 5 例， $4.0 \%$ にられたが， 3 例は一過性であった。穿孔は 4 例， $3.2 \%$ にられ，2 例に恥骨上ドレナージ， 2 例に 開腹縫合を行った. 切除不足により再 TUR を要した 症例が 4 例，3.2\%あった。その他，一過性精神障害 3 例, 敗血症, 逆行性射精, 肺炎, 肝炎, 尿道狭窄など が各 1 例認められた。 また, 合併症には含めなかった が, 術後も排尿障害持続し, 内視鏡および神経学的検 查にて神経因性膀胱之診断した症例が 5 例あった。

（3）併発悪性腫瘍

手術前後を通じてみられた悪性腫瘍併発症例は 8 
例，6.6\%あり，前立腺癌 5 例， $4.1 \% （ 1$ 例は尿路移 行上皮癌との併発) の他, 膀脱癌, 腎細胞癌, 陰茎癌 の各 1 例であった。前立腺癌はTURP の組織片での 診断が 3 例, 術後 2 年, 3 年の発症が各 1 例であり, 何れも抗男性ホルモン療法を行った。術後 2 年の発症 例は発症時すでに骨, 肝転移がみられ 6 力月後に肝不 全で死亡した。また， 3 年後の診断例は，TURP 時, 原因不明の左水腎症がみられ，左尿路腫瘍を疑い，精 査予定したが，患者の同意得られず， 2 年半後，左腎 尿管摘出，さらに 1 年後, 膀胱全摘兼右尿管皮膚瘦造 設施行し, 腎盂, 尿管, 膀胼ともに移行上皮癌であり, 同時に stage $\mathrm{A}_{1}$ の前立腺癌が発見されたものであっ た。

\section{4) 併行手術}

TUR に付随して行った手術は30例，24\%であり，そ の内訳は精管結禁術 14 例, $11.2 \%$, 前立腺穿刺生検 6 例, $4.8 \%$, 外尿道口切開術 3 例, $2.4 \%$ な゙であった。

\section{考 察}

前立腺肥大症の手術療法の first choice としての TUR の評価は確立された感がある。しかし，TUR と open surgery の手術成績の比較の報告は意外に少な (1) 5)。術式の選択は術者の好みによるが, TURは

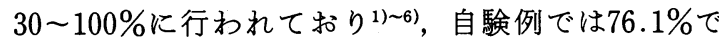
あった. 手技の向上により, TUR の頻度はさらに増す と思われるが，その限界についても後述する如く考慮 されるべきであろう。

患者の年齢は60 79歳が大半を占めるとの報告が多 く，自験例でも同様であったが，80歳台の症例は $\mathrm{O}$ 群 （2.7\%）に比しT群 $(11.6 \%)$ に多く, 平均寿命の延 長にともない, この点でも，TURの増加が見込まれ る.

高齢で合併症の多い本症患者の麻酔は腰麻や硬膜外 麻酔が適当とされるが3(4)667), 自験例はT群で腰麻が多 かったものの, O群では全麻が多く, 一考を要す問題 である。

T群とO群の術後経過の比較の報告によると, 術後 血尿期間, カテーテル留置期間, 入院期間は, 各, $\mathrm{T}$ 群で3.6〜6.9日，4.2〜7.0日，14.1〜18日，O群で 7 ～8 日，10１1日，20２5日であり， T群が優れてい るが(1) 5)，我々の成績でも，2.1対5.7日，4.3対10.7日， 15.4対25.5日の如く，T群が優る結果であった。

術中出血量について, 河野ら ${ }^{21}$ は TUR の灌流液中の $\mathrm{Hb}$ 量より出血量を算出し, O群の $770 \mathrm{~g}$ に対し $547.8 \mathrm{~g}$ と報告したが, 出血量の比較は困難であり, 臨床的に
判断された輸血量はT群が少ない傾向であった ${ }^{1 / 3)}$. 自 験例の輸血頻度も0群 $71 \%$ に対し T群 $34 \%$ と, T群が 少なかったが, 後述の如く, T群の出血量が過少評価 されている可能性がある。

術後合併症では, 副辠丸炎, 尿路感染症, 創感染, 出血などが主なものであり，T群で $10 ３ 0 \% ， \mathrm{O}$ 群で 10 40\%とされるが1) 5), 出血や尿路感染症の合併症 としての基準が報告者により異なると思われるので, 合併症の多寡の比較は困難である. 我々の症例では, 術後の膿尿はほぼ全例にみられたが，発熱をともなわ ないものは合併症とみなさず，一方，術後の強血尿や 1 力月以内の再出血を合併症としたため, 出血が最も 多く, その他, $\mathrm{T}$ 群では副辠丸炎, 尿失禁, 穿孔, 再 TUR など, O群では肝炎, 副睪丸炎, 瘦孔などが主と してみられ, 合併症の発生率には, 両群間に有意差が なかった。な拉，死亡はT群に 1 例， $0.8 \% ， \mathrm{O}$ 群に 1 例， $2.6 \%$ みられ，0 1.3\%，0５.7\%とした報 告2)3) 9) と同等であった。しかしながら, 報告例の多く は心筋梗塞, 腎不全, 脳出血などに起因しているのに 対し ${ }^{377)}$ ，自験例は出血が契機となって発症した DIC ( $\mathrm{T}$ 例)，ストレス胃潰瘍（O例）が死因であり，大い に反省させられた。

TUR の問題点に灌流液中の出血量測定の困難性と 灌流液吸収による TUR 反応があげられる. Melchior ら 下を，平岡 ${ }^{10}$ は Ht $3.4 \%$ の低下をみているが，我々の 検討でも，24時間後にT群で $\mathrm{Hb} 1.7 \mathrm{~g} / \mathrm{dl}, \mathrm{Ht} 5.6 \%$, $\mathrm{O}$ 群で $\mathrm{Hb} 1.0 \mathrm{~g} / \mathrm{dl}, \mathrm{Ht} 2.9 \%$ の低下がみられ，T群で の低下度が著しかった。一般に TURでは open surgery に比して出血量が少ないと言われているが, 我々 の検討から， O群の輸血症例の多いこと，T群での灌 流液の吸収，手技上の問題点などを考虑しても， T群 に㧍ける相当量の出血が推測され，O群との差はあま りないものと思われる。

一方, TUR 中の灌流液の吸収は $100 \sim 1,000 \mathrm{ml}^{11)}$, さ らに, 静脈洞の開口により, $4,000 \sim 8,000 \mathrm{ml}$ にょよ ぶ12) とされ, 長時間の手術では低 $\mathrm{Na}$ 血症や溶血を中 心とした homeostasis の乱れ，すなわち TUR 反応が 惹起される危険がある. Melchior ら ${ }^{7)}$ は術後血清 $\mathrm{Na}$ 值 $125 \mathrm{mEq} / \mathrm{L}$ 以下を fluid absorption toxicity とみな し， 20 例， $0.9 \%$ みている. 自験例では 1 例， $0.8 \%$ に，かかる症例がみられたが，血清 Cr., C1., K值とも に著しい異常例はみられず, これらの平均值において, O群との間に有意差は認められなかった。 
手術時間, 切除量, 切除率は各, $\mathrm{T}$ 群では欧米で $38 \sim 64$ 分, $11.3 \sim 47.6 \mathrm{~g}, 0.18 \sim 1.47 \mathrm{~g} / \mathrm{min}^{713)}$, 本邦で $64 \sim 94.5$ 分, $6.8 \sim 22.2 \mathrm{~g}, 0.1 \sim 0.33 \mathrm{~g} / \mathrm{min}^{1) \sim 410)}$, 本邦 の $\mathrm{O}$ 群で74.2 122分, 36〜 52.3g，0.34 0.53g/ $\mathrm{min}^{1) \sim 49)}$ と報告されている。われわれの成績ではT群 で69.8分， $16.2 \mathrm{~g}, 0.23 \mathrm{~g} / \mathrm{min}, \mathrm{O}$ 群で141.3分, $44.3 \mathrm{~g}$, $0.31 \mathrm{~g} / \mathrm{min}$ であり, 本邦報告例と比較すると, T群で 平均的, $\mathrm{O}$ 群でやや劣る結果であったが，その理由は 技術的要因もさることながら，矢崎ら4も述べている 如く, 教育病院の事情にもよると考学られる。また, 手術時間と切除量の関連については, T群では, 有意 に正の相関関係がみられたが，O群では関連性なく， 特に切除量 $40 \mathrm{~g}$ 以下では, $\mathrm{T}$ 群の切除率 $0.23 \mathrm{~g} / \mathrm{min}$ に 対し, $0.20 \mathrm{~g} / \mathrm{min}$ の如く, T群の優る傾向がみられ (Fig. 1), 自験例では, 腺腫 $40 \mathrm{~g}$ あたりに TUR の適応 基準が設定可能と思われた。

次に, TUR の成績について考察する.

TUR に限らず, 手術成績を左右する因子として, 一 般に術前の感染症, 賓血, 腎機能障害の有無, そして 年齢などが重要であり, さらに, TUR の特殊性から, 手術時間の延長, 切除量の増加にしたがって合併症の 増加が懸念される.TUR の成績の評価は困難であり, 自験例でも, 術後のカテーテル留置期間や入院期間な どは患者の希望や医師側の都合にも影響され，必ずし も成績の指標とはなり得ないが, 術後の血尿期間や合 併症とともに, 一応，成績の指標として検討した。

術前カテーテル留置症例は排尿障害が強く, 尿路感 染や腎機能障害例が多く，手術成績に影響すると思わ れるが, Melchior らフは術前のカテーテル留置は, 高 窒素血症がなければ, 術後の合併症率や死亡率に悪影 響をおよぼさなかったとしている.自験例では, カテー テル留置症例は術後入院期間が長く, 合併症の多い傾 向を示したが, 膿尿の有無による比較に拈いても, 膿 尿症例は入院期間が長く, 合併症が多く, 膿尿症例 51 例中 42 例, $82.4 \%$ がカテーテル留置例であることから, 成績不良の主因は, 留置カテーテルょりも膿尿にある と考学られ，かかる例では術前に尿路感染を充分コン トロールし, 可及的留置カテーテルを設置しないこと が望ましいだろう。

本症に併発する腎機能障害は15～25\%にみられると され ${ }^{14)}$, Melchior らは BUN 25mg/dl あるいは Cr 1.5 $\mathrm{mg} / \mathrm{dl}$ 以上を腎機能障害とし, $18 \%$ にみ ${ }^{7)}$, 手術死亡率 は腎機能正常例の 6 倍に達すると報告している ${ }^{15)}$. 門 脇ら ${ }^{16)}$ も Cr. $1.6 \mathrm{mg} / \mathrm{dl}$ 以上の腎機能障害例を $4.4 \%$ に
み, 術後合併症の発生率は腎機能正常例の $9.5 \%$ に対し 15\%と高率であったが，死亡例や重篤な合併症はみら れず, Cr. 1.6 3.0 $\mathrm{mg} / \mathrm{dl}$ 程度の症例に対しても, TURP は安全であると述べている. 自験例での高窒素 血症は $15.9 \%$ にられ，術後経過に打いて，対照群と の間に有意差は認められなかったが，その理由は $\mathrm{BUN} 35 \mathrm{mg} / \mathrm{dl}, \mathrm{Cr} 2.2 \mathrm{mg} / \mathrm{dl}$ 以下の軽症例であったこ とによると思われる。

Melchior ら ${ }^{7}$ は死亡例は腎機能障害例に次いで貧 血例の多いことを認めているが，われわれの貧血例の 術後経過には特に異常は認められなかった。 その理由 は，本邦と異なり，欧米の貧血例は腎不全や尿路感染 に付随したものが多いことによると思われる。

年齢と術後経過に関して, 80 歳以上の症例は手術侵 襲の小さいTUR が適応であるとされるが17), 一方, 80 歳以上では合併症, 死亡例が増加するとの報告もみら れ7)，一般に80歳以上ではリスクが高くなると思われ る. 自験例でも 80 歳以上の症例に成績不良の傾向がみ られ, 死亡の 1 例は 83 歳であり, この症例は術前検査 に異常は認められなかったが, かかる高龄者では, 心， 肺, 肝, 腎など諸臓器の機能低下とともに予備能低下 も予想され，少しのストレスにより出血傾向などの異 常事態の発生する可能性を常に念頭に扣き, 能率的, 愛護的に手術を施行すべきであろう。

手術時間に関して, 従来, TUR 反応の予防対策とし て, 60分を限度とすべきであると教えられてきたが12)， 近年，灌流液，輸液，麻酔の進歩により，この鉄則は 形骸化した感がある. Holtgrewe and Valk ${ }^{18}$ は azotemia がなければ, 手術時間を 1 時間に制限する必 要はないとし，Melchior ら7)も手術時間150分までは 予後に影響なかったとしている，本邦では 2 時間以内 が安全とされ ${ }^{10)}$, 自験例では, 91 分以上の長時間群は, 予期した如く, 切除量が多く, 血尿期間，カテーテル 留置期間は長かったが，入院期間はむしろ中時間群が 長く, 症例数不足もあって, 合併症に有意差は認めら れなかった。しかし，死亡を含む重大な合併症は手術 時間 120 分以上の症例に多くみられ，手術時間は 120 分 以内にとどめることが望ましい，われわれの手術時間 にはレジデントの指導に要した時間も含まれているの で, 正確とは言えないが, かかる点を考慮すると, TUR は開創手術と異なり，術者一人の方が能率的，有利で あると言える。

前述の如く, TUR の手術時間と切除量は平行関係 にあり, 当然, 切除量にも限度があるので, 予め, 腺 
腫重量を臨床的に評価できれば好都合である，Bissada ら ${ }^{19}$ は術前に直腸診と内視鏡検査により腺腫重 量を評価し, $50 \mathrm{~g}$ 以下のものを TUR に供したが, 超音 波診断の方が，より客観的，正確である20211.

切除量は術者の技術, 経験, 気性などに左右される ので, 腺腫重量から TUR の適応基準を設定すること には無理もあるが, その上限を, 欧米では50 80 $\mathrm{g}^{712922)}$, 本邦では50g としている(10)21). 結局, 術者が reasonable time に快適に切除できる量が最大切除可 能重量ということになり ${ }^{10119)}$, 自験例では, 120 分に52 $\mathrm{g}$ を切除したものが最大であったことから，40～ $50 \mathrm{~g}$ の切除を要する腺腫を TUR の適応上限と考光たい。

術後合併症は $6 \sim 30 \%$ に報告され(1) 5(7)10), 出血, 副 瞕丸炎, 尿路感染, 尿道狭窄などが主なものである。 出血は術者の技術に大いに左右され，尿路感染はほぼ 必発であるが, 術前, 後のカテーテル留置期間との関 連も示されている(1)34)23). 副睪丸炎は0.9 5\%に報告 されており 4)1023) 25), その病因, 予防に関し, 種々論議 されているが26), 結局, 術前に尿路感染のある場合, 特 に留置カテーテル設置例に拈いてのみ, 術前の精管結 禁術，抗生剤投与に予防効果があるようである。自験 例も 121 例中 5 例， $4 \%$ に副殬丸炎がみられ, 全例, 術 前尿路感染を有していたが，精管結禁術を行なった14 例（4 例は尿路感染例）にはみられず，この関連を立 証した結果であった，尿道狭窄は $4 \sim 12 \%$ と報告さ れ27), その病因は切除鏡や留置カテーテルによる尿道 粘膜の損傷や炎症にあり, 予防として, 術前の充分な 尿道計測, ていねいな尿道㧪張, 無理のない切除鏡や カテーテルの使用, 充分な尿道ゼリーやューチゾン軟 衰の使用などがあげられる $2.2 \sim 3.8 \%$ と報告され12210), 自験例では 1 例, $0.8 \%$ の みであり, 欧米の報告に比し, 少ない傾向が認められ た. 尿失禁, 穿孔, 再 TUR などの技術的な問題に起因 する合併症の報告は少ないが7，われわれは各，1.7\%， $3.2 \% ， 3.2 \%$ 経験した。これらは，技術の習熟によ り, 解消されるべきである. その他, 一過性精神障害, 敗血症, 逆行性射精, 肺炎, 肝炎などを認めたが, 逆 行性射精は, 実際にはもっと多いものと思われ, 40〜50\%にみられるとされる29).

Cote $ら^{30}$ は TURP 前後の urodynamic studyを検 討し, 長期の排尿障害例では, 術後の症状改善をみな い detrusor hyperrflexia の症例のあることをあげて いる.われわれの 5 例， $4.1 \%$ に神経因性膀胱がみられ たが, TURP の適応に際し, かかる症例の存在に留意
すべきであろう。

併発悪性腫湯に関して, Melchior $ら^{7)}$ は前立腺以外 では, 膀胀 (3.8\%) と腸管 $(2.4 \%)$ に多く, 前立腺 癌を $12 \%$ に認めている。自験例では, 術後経過中に発 見した 2 例の前立腺癌を含め, 8 例, $6.6 \%$ に悪性腫瘍 の併発を認めたが, 術後 2 年に発症した前立腺癌の 1 死亡例を除き，予後に影響はみられなかった. TUR 後 に偶然発見される前立腺癌の合併は $5 \sim 22 \%$ とされ, 偶発性, 潜在性前立腺癌の管理に関し, 種々論議され ており,一般に, 予後は良好と言われているが, diffuse, less differentiated case は stage B と同様に対処され るべきであろら ${ }^{31}$. 本邦での TUR 後の偶発性前立腺 癌は2.4 20.6\%に報告され(3)532), 自験例では 5 例, $4.1 \%$ （2 例は術後発生例）にみられたが, 全切片の詳 細な病理組織学的検索により, さらに増加するものと 思われる。

TURPに付随して行なった手術は精管結禁術と外 尿道口切開術であり，その理由は前述の如くである。 その他, 直腸診にて前立腺癌が疑われ, 穿刺生検を 6 例に行なったが，何れも陰性であった。

\section{結語}

1） 1976 年 1 月より 1983年12月までの 8 年間に杏林 大学附属病院泌尿器科にて手術を行なった前立腺肥大 症159例を open surgery 38例と TUR 121例に分け, 比較検討した。

2）術後の血尿期間，カテーテル留置期間，入院期間 などは，何れもTUR 群の方が短く，優れていた。

3）手術時間と切除量の間に, TUR 群では, 正の相 関関係がみられ, 切除量 $40 \mathrm{~g}$ 以下では, TUR 群の成績 が優る傾向を示した。

4）TURの適応基準を設定すべく，TUR 症例につ いて，諸因子に関して検討した。

5）TURの成績を左右する因子は, 術前の留置力 テーテル, 尿路感染, 年齢, 手術時間, 切除量などで あった。

6）以上の結果より，安定したTURを行ならため に, 発症後は早期に手術を考虑し, 可及的, 留置カテー テルを設置せず, 尿路感染を抑え, $50 \mathrm{~g}$ 以下の切除を要 する腺腫を適応とし，2 時間の手術時間を順守するこ とが，肝要と考えられた。

本論文の要旨は第50回日本泌尿器科学会東部総会におい て発表した。

\section{文献}

1）野口和美, 宮井啓国, 高井修道：前立腺の手術, 臨 
泌，32，441-446， 1978.

2）河野博己，加野資典：TUR-P と Open prostatectomyの手術成績の比較。西日泌尿，42, $69-72,1980$.

3）中島 均, 由井康雄, 秋元成太：前立腺肥大症の手 術療法に対する臨床的検討. 泌尿紀要, 31, 101-106, 1985.

4) 矢崎恒忠, 北川龍一, 加納勝利, 小川由英, 高橋茂 喜, 林正健二, 根本良介, 根本真一, 梅山知一, 武 島 自, 飯泉達夫, 内田克紀, 菅原公男, 石川 悟： 前立腺肥大症の手術療法に関する臨床的検討。日 泌尿会誌，73，1277-1288，1982.

5）横田武彦：前立腺肥大症の手術成績。西日泌尿, 41, 77-85, 1979.

6）藤田公生：経尿道的切除643例の経験. 日泌尿会 誌, 69, 611-614, 1978.

7) Melchior, J., Valk, W.L., Foret, J.D. and Mebust, W.K. : Transurethral prostatectomy: Computerized analysis of 2,223 consecutive cases. J. Urol., 112, 634-642, 1974.

8）岡 直友, 过村俊策, 井上四郎：本教室22年間の恥 骨後式前立腺摘出術の成績. 泌尿紀要, 22, 421-430， 1976.

9）秋志田裕人, 上田公介, 杉浦 式：恥骨後式前立腺 摘除術の成績。手術， 30，69-75，1976.

10）平岡保紀：経尿道的前立腺切除術の手術成績。臨 泌, 36, 765-768, 1982.

11) Zincke, H. and Nunnemann, R.: Transurethral prostatic resection: Complications in immediate postoperative period. in Transurethral Surgery, Greene, L.F. and Segura, J.W. ed., p. 181, W.B. Saunders Co., Philadelphia, London, Tronto, 1979.

12）南 武, 小柴 健：経尿道的切除術手技. p. 113, 金原出版, 東京, 1967.

13) Mackenzie, A.R., Levine, N. and Scheinman, Z.: Operative blood loss in transurethral prostatectomy. J. Urol., 122, 47-48, 1979.

14) Roberts, J.A. and Lewis, R.W.: Effect of obstruction on renal function. in Benign Prostatic Hypertrophy, Hinman, F. Jr. ed. p. 730, Springer-Verlag, New York, Heiderbeg, Berlin, 1983.

15) Melchior, J., Valk, W.L., Foret, J.D. and Mebust, W.K.: Transurethral prostatectomy in the azotemic patient. J. Urol., 112, 643-646, 1974.

16）門脇和臣, 鎗水史朗, 小柴 健：腎機能障害患者に 対する経尿道的前立腺切除術 (TURP)の臨床的検 討. 日泌尿会誌, 71, 1097-1104，1980.

17）高井修道：前立腺肥大症の各種治療法. 治療, 44, 1266-1277, 1962.

18) Holtgrewe, H.L. and Valk, W.L.: Factors influencing the mortality and morbidity of $t$ ransurethral prostatectomy: A study of 2,015 cases. J. Urol., 87, 450-459, 1962.
19) Bissada, N.K., Finkbeiner, A.E. and Redman, J. F.: Accuracy of preoperative estimation of resection weight in transurethral prostatectomy. J. Urol., 116, 201-202, 1976.

20）猪狩大陸：経直腸的超音波断層法を用いた前立腺 の大きさと形状に関する臨床的観察. 日泌尿会誌, 67, 28-39, 1976.

21）宮崎良春, 山口秋人, 角田和之, 南里和成, 原 孝 彦, 原 三信：前立腺肥大症に括ける経直腸的超 音波断層法の臨床的意義一ことに TUR の適応決 定と切除腺量の予測について一. 日泌尿会誌, 71, 378-382, 1980.

22) Lund, B.-L. and Dings $\phi$ r, E.: Benign obstructive prostatic enlargement. A comparison between the results of treatment by transurethral electroresection and the results of open surgery. Scand. J. Urol. Nephrol., 10, 33-38, 1976.

23) Jackman, F.R. and Chisholm, G.D.: Urinary infection and prostatectomy. Brit. J. Urol., 47, 545-548, 1975.

24) Melchior, J., Valk, W.L., Foret, J.D. and Mebust, W.K.: Transurethral prostatectomy and epididymitis. J. Urol., 112, 647-650, 1974.

25) Brooks, M.B., Lytton, B. and Weiss, S.A.: Vasectomy in the control of epididymitis after prostatectomy following urethral catheter drainage method. J. Urol., 105, 694-697, 1970.

26) Silber, S.J. and Nesbit, R.M.: Transurethral resection: Infection and antibiotics, 199-203, A.C.C., New York, 1977.

27) Warres, H.L.: Urethral stricture following transurethral resection of the prostate. J. Urol., 79, 989-993, 1958.

28) Lentz, H.C. Jr., Mebust, W.K., Foret, J.D. and Melchior, J.: Urethral strictures following transurethral prostatectomy: Review of 2,223 resections. J. Urol., 117, 194-196, 1977.

29) Johnson, D.E., Swanson, D.A. and Eschenbach, A.C.: Tumors of the genitourinary tract. in General Urology, Smith, D.R. 11th ed. p. 341, Lange Maruzen, California, 1984.

30) Cote, R.J., Burke, H. and Schoenberg, H.W.: Prediction of unusual postoperative results by urodynamic testing in benign prostatic hyperplasia. J. Urol., 125, 690-692, 1981.

31) Silber, S.J. and Nesbit, R.M.: Transurethral Resection: Unsuspected cancer found at TUR for presumed benign obstruction, 151-162, A.C. C., New York, 1977.

32）大西哲郎, 飯塚典男, 田所 衛, 品川俊人：経尿道 的前立腺切除後の病理検索で発見された偶発性前 立腺癌13例についての検討. 第 434 回日本泌尿器科 学会東京地方会.

（1985年11月 20 日受付） 